Keywords:

Ectomycorrhizae

Red angico

Forestry production

Mycorrhization method

Essential oils

Histórico:

Recebido 04/04/2017

Aceito 19/05/2017

Palavras chave:

Ectomicorrizas

Angico-vermelho

produção florestal

método de micorrização

óleos essenciais

+ Correspondência:

ge.pauli@yahoo.com.br

DOI:
Gerusa Pauli Kist Steffen ${ }^{+}$, Ricardo Bemfica Steffen², Rosana Matos de Morais', Cleber Witt Saldanha', Joseila Maldaner', Táscilla Magalhães Loiola ${ }^{3}$

\section{Parapiptadenia rigida MYCORRHIZATION WITH SPORES OF Scleroderma citrinum}

ABSTRACT: Ectomycorrhizal fungal inoculation in forestry seedlings aids plant establishment and growth in the field. The objectives of this study were: to determine the mycorrhizal capacity of the ectomycorrhizal fungus Scleroderma citrinum in Parapiptadenia rigida (red angico) seedlings and to evaluate the viability of a mycorrhizal inoculation technique for forest seedlings involving the use of spores. Mature spores were inoculated in the substrate $(75 \%$ soil and $25 \%$ carbonized rice husk), totaling 1.5 grams of fungal spores per liter of substrate. $P$. rigida seeds were sown in substrates inoculated or not inoculated with fungal spores in presence or absence of Pinus echinata and Eucalyptus citriodora essential oil: not inoculated $(\mathrm{TI})$, inoculated (T2), inoculated more pine essential oil (T3), inoculated more eucalyptus essential oil (T4). Seedlings of Pinus elliottii were used for a positive control of mycorrhizal inoculation (T5) and not inoculated (T6) with fungal spores. At 90 days after sowing, the base stem diameter, height, fresh and dry weight of shoots and roots, percentage of root colonization and Dickson Index were determined. The presence of fungal structures in $P$. rigida and $P$. elliottii roots inoculated with $S$. citrinum spores was observed, demonstrating the occurrence of an ectomycorrhizal association. The application of pine and eucalyptus essential oils in the substrate increased the percentage of ectomycorrhizal colonization in $P$. rigida seedlings. The addition of $S$. citrinum mature spores in the substrate used for seedling production is a viable practice for ectomycorrhizal inoculation and it can be used in forest nurseries in controlled mycorrhization programs.

\section{MICORRIZAÇÃO DE Parapiptadenia rigida COM ESPOROS DE Scleroderma citrinum}

RESUMO: A inoculação de fungos ectomicorrízicos em mudas florestais beneficia o estabelecimento e crescimento das plantas no campo. Os objetivos do trabalho foram: determinar a capacidade de micorrização do fungo ectomicorrízico Scleroderma citrinum em mudas de Parapiptadenia rigida (angico-vermelho) e avaliar a viabilidade da técnica de inoculação micorrízica de mudas florestais através do uso de esporos. Esporos maduros foram inoculados ao substrato ( $75 \%$ solo e $25 \%$ casca de arroz carbonizada), totalizando I,5 gramas de esporos de fungo por litro de substrato. Sementes de $P$. rigida foram semeadas em substratos inoculados ou não com esporos de $S$. citrinum, na presença ou ausência dos óleos essências de Pinus echinata e Eucalyptus citriodora: não inoculado (TI), inoculado (T2), inoculado mais adição de óleo essencial de pinus (T3), inoculado mais adição de óleo essencial de eucalipto (T4). Mudas de Pinus elliottii foram utilizadas para controle positivo da inoculação micorrízica, inoculadas (T5) e não inoculadas com esporos ectomicorrízicos (T6). Aos 90 dias após a semeadura, foram determinados o diâmetro do colo, a altura, as massas fresca e seca da parte aérea e das raízes, o percentual de colonização radicular e o Índice de Dickson. Observou-se presença de estruturas fúngicas no interior das raízes de $P$. rigida e $P$. elliotti inoculadas com esporos de $S$. citrinum, evidenciando a ocorrência de associação ectomicorrízica. A aplicação dos óleos essenciais de pinus e de eucalipto no substrato elevou o percentual de colonização ectomicorrízica nas mudas de angicovermelho. A adição de esporos maduros de $\mathrm{S}$. citrinum ao substrato de produção das mudas representa uma prática viável de inoculação ectomicorrízica, com possibilidade de utilização em viveiros florestais em programas de micorrização controlada.

State Foundation for Agricultural Research - Santa Maria, Rio Grande do Sul, Brazil

${ }^{2}$ Renovagro - Uberaba, Minas Gerais, Brazil

${ }^{3}$ University of the State of Santa Catarina - Florianópolis, Santa Catarina, Brazil 


\section{INTRODUCTION}

The symbiotic interaction of ectomycorrhizae with forest species is considered very beneficial, especially in areas of degraded and fragile soil, commonly found in the Pampa biome of Rio Grande do Sul, Brazil (NARA; HOGETSU, 2004).

The need for mycorrhization of forest species was demonstrated for the first time by Frank( 1894), although the first records of mycorrhizae are from 1840, when R. Hartig illustrated the Pinus sp. root system (TRAPPE; BERCH, 1985). Among the several genera of ectomycorrhizal fungi (fECM), Scleroderma, Hysterangium and Rhizopogon stand out as important biotechnological resources to be used in forestry (SULZBACHER, 20I0), due to the benefits that the ectomycorrhizal association provides in plants. These benefits include increased water and nutrient absorption capacity, a higher tolerance to abiotic stresses (salinity, drought and presence of heavy metals) and suppression of pests and plant diseases (CARDOSO FILHO et al., 2016).

Scleroderma genus comprises several species of epigeal fungi that grow in the soil and present a globid to subglobous basidiocarp, with a smooth to scaly surface, and the glebe is lumpy (non pulverulent). Natural dehiscence occurs by rupturing the apical portion of the periode, which releases spores (WRIGHT; ALBERTÓ, 2006). Scleroderma sp. belongs to the Sclerodermataceae family, which presents seven genera, of which only four have been previously studied as ectomycorrhizae, including the genus Scleroderma (GURGEL, 2009). The ectomycorrhizal character of Scleroderma sp. has been known for a long time (GURGEL et al., 2008; SOYTONG et al., 20l4), however, little is known about the diversity and the association ability of species of this genus with host plants in tropical regions and, mainly, in native forest environments in South America and Brazil (GURGEL, 2009).

Scleroderma citrinum Persoon has a wide distribution in the southern region of Brazil (OLIVEIRA et al., 20I0; SULZBACHER et al., 2013) and is also found in the northeastern region, in the states of Paraíba (GURGEL et al., 2008) and Rio Grande do Norte (GURGEL, 2009). They naturally inhabit the surface of sandy soils and trunks of live trees in Pinus sp. forests, plantations of $P$. elliottii Engelm. and Pinus taeda L., being associated to the root system of plants of this genus (GURGEL et al., 2008; SULZBACHER et al., 20I3).

Ectomycorrhizae presents specificity in relation to their symbiont (SMITH; HEAD, 2008), which can be manifested between genera (BAHRAM et al., 20I3). According to Raudaskoski and Kothe (20I5) this specificity is related to the fungal species dependence on the presence of specific biochemical signals produced by the host plant. There are reports of the positive effect applying secondary metabolites on the mycorrhization of native forest species under controlled conditions (STEFFEN et al., 2012). These results are of interest for the forest sector because of the lack of consensus regarding the occurrence of ectomycorrhizal associations in native Brazilian forest species, being considered rare in natural conditions (OLIVEIRA et al., 2008).

In Brazil, although ectomycorrhizal associations between species of the genus Pinus and Eucalyptus are known, little is known about symbiosis with native forest species (GURGEL, 2009; SULZBACHER et al., 2013), which is the case of Parapiptadenia rigida (Benth) Brenan, commonly known as red angico. This species belongs to the Fabaceae family, and is frequently found in the states of southern Brazil, as well as the state of Mato Grosso do Sul and Minas Gerais. It presents heavy wood (density

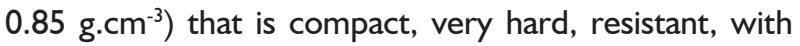
little elasticity and great durability in natural conditions. It can be used in hydraulic and exposed works, for the construction of resistant pieces, truck bodies, civil and naval construction, carpentry, firewood and charcoal (LORENZI, 20I4). The tree bark is rich in tannin and because of its exuberant flowering, it is a suitable species for ornamentation and landscaping, as well as reforestation programs for the recovery of degraded areas (LORENZI, 20I4).

In programs of controlled mycorrhization of forest species, the common method used for ectomycorrhizal inoculation is the addition of fungal mycelium to the substrate for seedling production. Mycelial propagules are derived from the multiplication of pure cultures in the laboratory, which are then fragmented and added to the sterile substrate (vermiculite, peat), generating the ectomycorrhizal inoculum. Another form of inoculant production is the multiplication of the mycelium directly into a solid substrate, composed of a mixture of vermiculite and peat enriched with nutrient solution. Although efficient, adoption of these methodologies may be difficult in mycorrhizal programs and requires investments in infrastructure for the largescale production of the ectomycorrhizal inoculant. Some of the difficulties are the constant maintenance of the species in the laboratory, the long periods of cultivation under controlled conditions, the possible loss of fungus infection capacity over time (OLIVEIRA et al., 20I0) and reduced lifespan of the inoculum generated, which should preferably be prepared on the day of inoculation of the seedlings. Thus, it is believed that the use of ectomycorrhizal spores instead of vegetative propagules 
may be an efficient alternative for programs of controlled mycorrhization of forest species, to date an unpublished methodology because it is associated with the use of essential oils of hosts plants of fECM.

The objectives of this study were to determine the mycorrhizal capacity of fECM S. citrinum in P. rigida seedlings and to evaluate the viability of the ectomycorrhizal inoculation technique in forest seedlings using spores removed from mature sporocarps of $S$. citrinum.

\section{MATERIALS AND METHODS}

The substrate used for seedling production was composed of a soil mixture (75\%) and carbonized rice husk $(25 \%)$. Soil was used from the subsurface horizon of a native field, belonging to the class of Alfisols. The soil was air-dried, sieved in $2 \mathrm{~mm}$ mesh and autoclaved through three consecutive cycles of 60 minutes at $121^{\circ} \mathrm{C}$.

Six treatments were evaluated: I) $P$. rigida witness (without inoculation); 2) P. rigida + fungal spores; 3$) P$. rigida + fungal spores + pinus essential oil; 4) P. rigida + fungal spores + eucalyptus essential oil; 5) $P$. elliottii witness (without inoculation) and 6) $P$. elliottii + fungal spores. The $P$. elliottii treatment that received spores of $S$. citrinum was used as a positive control of mycorrhizae, since species of Pinus genus are hosts of $S$. citrinum.

Seeds of $P$. rigida and $P$. elliottii were obtained from the forest seed bank in the Forest Research Center of Fundação Estadual de Pesquisa Agropecuária (Santa Maria, Rio Grande do Sul state, Brazil), where they were stored in a cold room at $8{ }^{\circ} \mathrm{C}$ and $55 \%$ relative humidity. Both lots of $P$. rigida (collected in July 2013) and $P$. elliottii (collected in April 2013) were composed of seeds obtained in areas of seed collection in the municipality of Santa Maria. The dormancy of the pine seeds was achieved by immersion in water at room temperature for 24 hours.

Mature sporocarps of S. citrinum were collected in the surface of a natural field located under the canopy of a specimen of $P$. echinata at the Forest Research Center. Each fungus was carefully collected manually to avoid rupturing and exposing the spores contained within the globose basidiocarp. The fungi were then taken to the laboratory for removal and weighing of the spores. For the preparation of the substrate with $S$. citrinum inoculum, 38 grams of spores were added to 25 liters of substrate, totaling approximately 1.5 grams of spores per liter of substrate. The process of material homogenization occurred for about five minutes in a sealed concrete mixer.

Essential oils of Eucalyptus citriodora and Pinus echinata were extracted by hydrodistillation of fresh leaves (VITTI; BRITO; 2003). The collected leaves were cut into $2 \mathrm{~cm}$ pieces and placed in a round bottom flask of a modified Clevenger apparatus (SERAFINI; CASSEL, 200I), with boiling distilled water kept in the vessel by means of an external heater. After the distillate passed through a condenser, the extracted plant components were collected and kept under refrigeration at $4{ }^{\circ} \mathrm{C}$ until use. The essential oils were solubilized in ethanol at a ratio of $\mathrm{I}: \mathrm{I}(\mathrm{v} / \mathrm{v})$, according to the methodology proposed by Fabrowski et al. (2003). Four $\mathrm{mL}$ of the solution containing essential oils were applied to the substrate of the corresponding treatments, at a concentration of 40 $\mu \mathrm{L} \mathrm{L} \mathrm{L}^{-1}$ for eucalyptus oil and $30 \mu \mathrm{L} \cdot \mathrm{L}^{-1}$ for pinus oil, $\mathrm{I} 5$ and $2 \mathrm{I}$ days after seeding, respectively.

Plastic tubes with a capacity of $100 \mathrm{~cm}^{3}$ were used, which were filled with the respective substrate for each treatment. Then, the two forest species were seeded (Winter, July month) and the experimental units were kept in a greenhouse (without internal temperature control). Moisture in the substrate was replaced daily, by adding distilled water.

The measurements were made 90 days after seeding, and the following parameters were determined: stem diameter $(\mathrm{mm})$, height of the seedling $(\mathrm{cm})$, fresh and dry mass of shoot and roots $(\mathrm{mg})$, percentage of root colonization, height/shoot dry matter and Dickson's Index (DICKSON et al., 1960). The base stem diameter was determined using a digital pachymeter. The height was determined with a millimeter ruler, obtained by the distance from the base of the plant to the end of the last leaf axils. Subsequently, the plants were cut at the height of the substrate and the root system was washed in running water. The shoot and the root system were dried in an air circulating oven at $65^{\circ} \mathrm{C}$ until reaching constant weight. Subsequently, the values of dry mass of shoot and roots were determined in an analytical balance with an accuracy of $0.01 \mathrm{~g}$.

Percentage of root colonization was determined by the intersection technique of Giovanetti and Mosse (1980), modified by Brundrett et al. (1996). The formation of ectomycorrhizae was evaluated using the anatomical characteristics of the roots, with crosssectional histological sections of the adventitious roots and the preparation of slides. The evaluation of the internal morphology was performed under an optical microscope, detecting the presence of the fungal mantle and the Hartig network (BRUNDRETT et al., 1996).

The experimental design was a randomized block design with six treatments and five replications, each replicate composed of six plants and the values of height, 
stem diameter, fresh and dry mass of the aerial part and roots and percentage of mycorrhizal colonization were submitted to analysis of variance and when there was significance the means were compared by the Tukey test with the aid of SISVAR software (FERREIRA, 20I I), based on significance levels higher than $95 \%(P \leq 0.05)$.

\section{RESULTS AND DISCUSSION}

The new methodology proposed in this paper that use mature spores of $S$. citrinum was shown to be efficient for mycorrhization of forest species. Fungal structures were on the inside and outside the roots of $P$. rigida inoculated with $S$. citrinum spores, demonstrating the occurrence of ectomycorrhizal association. Internally, the formation of the Hartig network, an intercellular mesh in the epidermis and in the root cortex, was observed. By covering the external surface of the roots (epidermis), the formation of a fungal mantle, a coating derived from the Hartig network, was observed (Figure I).

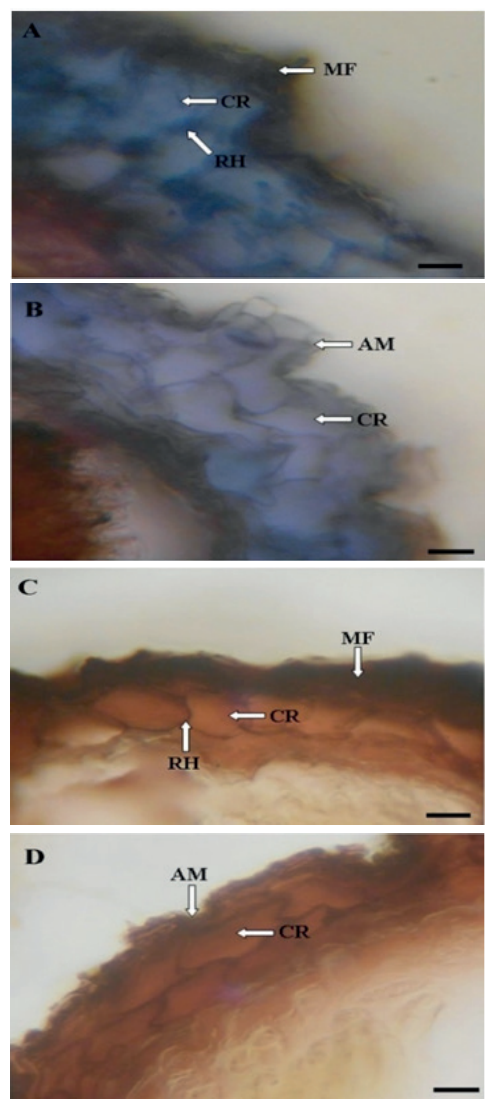

FIGURE I Cross-sections of Parapiptadenia rigida seedling roots inoculated (A) and non-inoculated (B) and Pinus elliottii seedling roots inoculated $(C)$ and noninoculated (D) with Scleroderma citrinum fECM spores. (AM) absence of fungal mantle, (CR) root cortex cells, (RH) Hartig net, (MF) fungal mantle. Scale $80 \mu \mathrm{m}$.
The radicular system of the plants associated to $\mathrm{fECM}$ is characterized by the presence of three components. In addition to the Hartig network and the fungal mantle, they present structures external to the root system, composed of hyphae and rhizomorphs, which are essential for the connection with the soil and the formation of fruiting bodies of the fECM (SMITH; READ, 2008). These structures are responsible for the temporary storage of nutrients and nutrient and carbohydrate exchange between the fungus and the plant (PETERSON et al., 2004; CECCAROLI et al., 20I5). In this paper these structures were observed in the roots of $P$. rigida inoculated with $S$. citrinum spores, proving the occurrence of ectomycorrhizal association (Figure I).

As observed in the $P$. rigida seedlings, the $P$. elliottii seeds inoculated with $S$. citrinum spores also generated seedlings with a fungal mantle in the root system, demonstrating the viability of the spore mass used in the experiment. The mean percentage of mycorrhizal colonization of the $P$. elliottii plant roots inoculated with fungal spores was $27.8 \%$ (Table I).

The addition of pine and eucalyptus essential oils to the substrate significantly increased the percentage of ectomycorrhizal colonization in the P. rigida seedlings, when compared to the percentage observed in seedlings inoculated in substrate without the presence of these compounds (Table I). These results corroborate with Steffen et al. (20I2), who observed that the application of Eucalyptus grandis essential oil at a concentration of $40 \mu \mathrm{L} \cdot \mathrm{L}^{-1}$ stimulated the occurrence of ectomycorrhizal association of Pisolithus microcarpus in Caesalpinia peltophoroides Benth. seedlings. In this study, it is possible that the presence of the majority of the compounds from

TABLE I Percentage of ectomycorrhizal colonization (EMC), height and stem diameter of Pinus elliottii and Parapiptadenia rigida seedlings inoculated and not inoculated with spores of Scleroderma citrinum fungus with Pinus echinata and Eucalyptus citriodora essential oils applied 90 days after sowing.

\begin{tabular}{|c|c|c|c|}
\hline Treatments & $\begin{array}{c}\text { EMC } \\
(\%) \\
\end{array}$ & $\begin{array}{c}\text { Height } \\
(\mathrm{cm})\end{array}$ & $\begin{array}{c}\text { Stem diameter } \\
(\mathrm{mm})\end{array}$ \\
\hline & \multicolumn{3}{|c|}{ Parapiptadenia rigida } \\
\hline Not inoculated & $0 \mathrm{c}$ & 8.91 a & $\mathrm{I} .64 \mathrm{~b}$ \\
\hline Inoculated & $10.0 \mathrm{~b}$ & $10.07 \mathrm{a}$ & $1.68 \mathrm{ab}$ \\
\hline Inoculated + pine oil & $18.4 \mathrm{a}$ & $10.36 \mathrm{a}$ & $1.89 \mathrm{a}$ \\
\hline Inoculated + eucalyptus oil & $20.3 \mathrm{a}$ & $10.35 \mathrm{a}$ & I.7I ab \\
\hline \multirow[t]{2}{*}{$\mathrm{CV}(\%)$} & 13.10 & 14.96 & 9.32 \\
\hline & \multicolumn{3}{|c|}{ Pinus elliottii } \\
\hline Not inoculated & $\mathrm{Ob}$ & $12.7 \mathrm{a}$ & $1.93 \mathrm{a}$ \\
\hline Inoculated & $27.8 \mathrm{a}$ & $13.3 \mathrm{a}$ & $1.88 \mathrm{a}$ \\
\hline CV (\%) & $\mathrm{II} .80$ & 10.11 & 7.89 \\
\hline
\end{tabular}

Averages followed by the same letter in the columns do not differ from each other, according to the Tukey test at $5 \%$ error probability. 
the secondary metabolism of the eucalyptus essential oil: Eucalyptol, p-Cymeno, Spathulenol, Lepidozenal, CubebI I-ene, Junenol and 4(I5)-Dehydroglobulol (STEFFEN et al., 2013) in the substrate contributed to the association between the fungus and the plant due to the occurrence of biochemical signaling (STEFFEN et al., 20I2).

No effect of the treatments on the height of the seedlings of either forest species was observed. However, the values of the stem diameter in the $P$. rigida seedlings varied, with higher in the seedlings submitted to inoculation with S. citrinum spores (Table I). These results corroborate assertions of Martins et al. (2005) that plant growth is influenced by mycorrhization, especially in relation to the height/diameter ratio at the base level, leading to greater robustness or thickening of the inoculated seedlings, compared to those that did not receive ectomycorrhizal inocula.

In addition to increasing the percentage of mycorrhizal colonization, the use of pine and eucalyptus essential oils promoted increases in the fresh and dry mass of shoots and roots of the $P$. rigida seedlings that grew in the presence of fECM (Table 2). This effect may be related to the greater intensity of mycorrhizal colonization of the plants corresponding to these treatments (Table I), as a result of the benefits provided by the symbiotic association. Another factor that may have contributed to the increase of shoot and root biomass is the direct effect of the application of essential oils. The use of some essential oils at certain concentrations may induce the growth of plants, insects and microorganisms, as verified by Bonaldo et al. (2007), Neilson et al. (2013), Haddi et al. (20I5) and Simas et al. (20I7).

TABLE 2 Fresh and dry mass of shoots and roots of Pinus elliottii and Parapiptadenia rigida seedlings inoculated and not inoculated with spores of Scleroderma citrinum fungus with addition of Pinus echinata and Eucalyptus citriodora essential oils at 90 days after sowing. Abbreviations: FMS - fresh mass of shoots, FMR - fresh mass of roots, DMS - dry mass of shoots, DMR - dry mass of roots.

\begin{tabular}{ccccc}
\hline Treatments & $\begin{array}{c}\text { FMS } \\
(\mathrm{g})\end{array}$ & $\begin{array}{c}\text { FMR } \\
(\mathrm{g})\end{array}$ & $\begin{array}{c}\text { DMS } \\
(\mathrm{g})\end{array}$ & $\begin{array}{c}\text { DMR } \\
(\mathrm{g})\end{array}$ \\
\hline \multirow{3}{*}{ Not inoculated } & \multicolumn{5}{c}{ Parapiptadenia rigida } \\
\cline { 2 - 5 } Inoculated & $0.479 \mathrm{~b}$ & $0.398 \mathrm{~b}$ & $0.177 \mathrm{a}$ & $0.087 \mathrm{~b}$ \\
Inoculated + pine oil & $0.482 \mathrm{~b}$ & $0.406 \mathrm{~b}$ & $0.194 \mathrm{ab}$ & $0.093 \mathrm{~b}$ \\
Inoculated + eucalyptus oil & $0.64 \mathrm{I} \mathrm{a}$ & $0.450 \mathrm{a}$ & $0.254 \mathrm{a}$ & $0.130 \mathrm{a}$ \\
CV (\%) & 8.34 & 11.32 & $12.22 \mathrm{a}$ & $0.104 \mathrm{a}$ \\
\cline { 2 - 5 } & \multicolumn{5}{c}{ Pinus elliottii } \\
\cline { 2 - 5 } Not inoculated & $1.036 \mathrm{a}$ & $0.643 \mathrm{a}$ & $0.307 \mathrm{a}$ & $0.195 \mathrm{a}$ \\
Inoculated & $1.254 \mathrm{a}$ & $0.795 \mathrm{a}$ & $0.426 \mathrm{a}$ & $0.221 \mathrm{a}$ \\
CV (\%) & 10.64 & 12.07 & 15.24 & 11.06 \\
\hline
\end{tabular}

Averages followed by the same letter in the columns do not differ from each other, according to the Tukey test at $5 \%$ error probability.
Positive effects of the addition of pine and eucalyptus essential oils were also observed on the $P$. rigida fresh and dry mass of shoots and roots that grew in the presence of fECM (Table 2). In relation to pine seedlings, no significant effects of ectomycorrhizal inoculation were observed on the stem diameter, fresh and dry shoot and root mass (Tables I and 2).

The root system of host plants of ectomycorrhizal fungi synthesize and provide preferential secondary metabolites of the fungal species, which act as biochemical signals that encourage chemo-tropism, favoring the establishment of the fungus-plant association (MIRANSARI et al., 20I4; PAGANO et al. 20I7). Thus, it is believed that the application of compounds derived from the secondary metabolism of symbiotic plants, such as species of the genus Pinus and Eucalyptus, may be a technological alternative to stimulate the establishment of associations between native forest species in Brazil and ectomycorrhizal fungi, whose symbiosis is quite common in these genera of exotic plants (STEFFEN et al., 2012). Species of the genus Pinus are hosts of S. citrinum (GURGEL et al., 2008) and do not develop normally if they are not associated with ectomycorrhizal fungi (MARTINS et al., 2005).

The height/shoot dry matter ratio should be considered in evaluations of the quality standard of the seedlings. Seedlings with lower mean values for the height/shoot dry mass ratio (H/DMS) have greater chances of survival in the field, since they are considered to be more lignified (CALDEIRA et al., 20II). In this study, the $P$. rigida and $P$. elliottii seedlings that presented the highest percentages of ectomycorrhizal colonization (Table I) presented lower mean H/DMS ratio (Table 3 ).

TABLE 3 Height dry mass of shoots ratio (H/DMS) and Dickson Index (DI) in Pinus elliottii and Parapiptadenia rigida seedlings inoculated and not inoculated with spores of Scleroderma citrinum fungus and the application of Pinus echinata and Eucalyptus citriodora essential oils 90 days after sowing.

\begin{tabular}{ccc}
\hline Treatments & H/DMS & DI \\
\hline & \multicolumn{2}{c}{ Parapiptadenia rigida } \\
\cline { 2 - 3 } Not inoculated & $50.33 \mathrm{a}$ & $0.035 \mathrm{~b}$ \\
Inoculated & $51.99 \mathrm{a}$ & $0.035 \mathrm{~b}$ \\
Inoculated + pine oil & $40.78 \mathrm{~b}$ & $0.05 \mathrm{I} \mathrm{a}$ \\
Inoculated + eucalyptus oil & $46.62 \mathrm{ab}$ & $0.039 \mathrm{~b}$ \\
$\mathrm{CV}(\%)$ & $13,4 \mathrm{I}$ & 17,83 \\
\cline { 2 - 3 } & Pinus elliottii \\
\cline { 2 - 3 } Not inoculated & $41.36 \mathrm{a}$ & $0.06 \mathrm{I} \mathrm{a}$ \\
Inoculated & $31.22 \mathrm{a}$ & $0.07 \mathrm{I} \mathrm{a}$ \\
CV (\%) & 12,66 & 10,85 \\
\hline
\end{tabular}


Higher values of the Dickson Index were observed in the $P$. rigida seedlings inoculated with the fECM in the presence of pine essential oil. For the $P$. elliottii seedlings, the highest value of this index was verified for the inoculated plants, showing that the establishment of ectomycorrhizal association provides higher quality to the seedlings produced (Table 3).

The ectomycorrhizal association of $P$. rigida and $P$. elliottii by direct inoculation of mature spores in the substrate for seedling production gave good results and may be a practical and effective technique for use in forest mycorrhization programs. In Rio Grande do Sul, the abundant fruiting of S. citrinum in Pinus sp. forests is observed in the months corresponding to autumn and winter. Therefore, in order to ensure the constant availability of spores in forest nurseries, mature sporocarps should be collected and stored in a dry and ventilated environment, in which they can last for several months to years (GLASSMAN et al., 2016). Thus, the spore supply for mycorrhizal seedlings would be guaranteed throughout the year, significantly reducing maintenance efforts when compared to the methodology that uses vegetative mycelium as an ectomycorrhizal inoculum.

In Brazil, although there is consensus about the many benefits of ectomycorrhizal inoculation for plants, the use of $\mathrm{fECM}$ inoculants in commercial seedling production systems is incipient (OLIVEIRA et al., 2010). One of the obstacles is the difficulty of mass production techniques for the ectomycorrhizal inoculants, which depend on a microbiology laboratory trained professionals to maintain the fungal isolates, since there is a lack of companies that market ectomycorrhizal inoculants for this purpose.

In this sense, the results obtained here show the viability of this new methodological possibility, which is low cost and would allow the formation of an ectomycorrhizal association not only in natural forest species of ectomycorrhizae, as in Pinus spp., but mainly in species that rarely associate with these microorganism symbionts in natural conditions, as is the case of native forest species in Brazil. In addition, the results serve as incentives for the establishment and preservation of forests for the collection and maintenance of fungal inocula of different ectomycorrhizal species of commercial interest. This method would also be environmentally sustainable, aiding to improve plant and animal components in natural habitats, which has been recognized as an important responsibility in relation to forest management.
The controlled mycorrhization of forest species in nurseries provides the establishment of young plants associated with mycorrhizal fungal strains (JOHNSON et al., 20I2), which may contribute to the improvement of the physiological conditions of plants, the ability to grow and adapt after transplantation in natural environments (HODGE; FITTER, 20I3). According to Johnson et al. (2012), after transplantation to the field, mycorrhizae ensure a higher rate of survival, growth and resistance to pathogens. Future studies to evaluate the effect of mycorrhization of native Brazilian species on the growth rate in field conditions, which is considered very slow in comparison to introduced species, could determine if the association with $\mathrm{fECM}$ is able to promote increases in the development of these forest species, which would also serve as an incentive for the planting of native species.

Being aware of the benefits of controlled inoculation of ectomycorrhizae in forest species and of the lack of information on the establishment of associations between fECM and Brazilian native forest species, researchers have directed efforts to carry out studies on this type of symbiosis under natural and controlled conditions (SILVA et al., 20II). Silva et al. (20II) observed formation of an ectomycorrhizal association between $P$. rigida seedlings, Peltophorum dubium (Spreng.) Taub. and Enterolobium contortisiliquum (Vell.) Morong with Pisolithus microcarpus (isolated UFSC-Pt I 16). The inoculation of the ectomycorrhizal species was carried out in vitro, by the addition of fungal mycelium to the substrate where the seedlings of the evaluated forest species were transplanted. The authors observed a reduction in root length, height and fresh root mass of mycorrhizal red angico seedlings with $P$. microcarpus when compared to non-mycorrhizal roots.

The knowledge of the diversity of ectomycorrhizal species and their associations with host plants is crucial for the determination of endangered species, as well as for creating strategies for the maintenance of ecosystem diversity, mainly in Brazil and in other poorly studied areas, in order to better understand the role of these fungi and their impacts on the environment (GURGEL, 2008). In this sense, new studies are needed to increase the knowledge about the dynamics of interactions between plants and microorganisms in native ecosystems of Brazil, aiming to generate a practical contribution to the improvement of seedling quality and establishment of native forest species in the environment. 


\section{CONCLUSIONS}

Parapiptadenia rigida seedlings form an ectomycorrhizal association with Scleroderma citrinum under controlled conditions of mycorrhization. The presence of Pinus echinata and Eucalyptus citriodora essential oils in the substrate of seedling production significantly increases the percentage of mycorrhizal colonization in $P$. rigida. The addition of mature spores of $S$. citrinum to the substrate used for the production of $P$. rigida and $P$. elliottii seedlings is a viable inoculation technique for use in forest mycorrhization programs.

\section{ACKNOWLEDGEMENTS}

The authors thank the Fundação Estadual de Pesquisa Agropecuária (FEPAGRO), for the infrastructure and the contribution of resources needed to carry out the work.

\section{REFERENCES}

BAHRAM, M.; KOLJALG, U.; KOHOUT, P.; MIRSHAHVALADI, S.; TEDERSOO, L. Ectomycorrhizal fungi of exotic pine plantations in relation to native host trees in Iran: evidence of host range expansion by local symbionts to distantly related host taxa. Mycorrhiza, v. 23, n. I, p. II-19, 2013.

BONALDO, S. M.; SCHWAN-ESTRADA, K. R. F; STANGARLIN, J. R.; CRUZ, M. E. S.; FIORI-TUTIDA, A. C. G. Contribution for the study of antifungal and phytoalexins elicitors in sorghum and soybean activities by eucalyptus (Eucalyptus citriodora). Summa Phytopathologica, v. 33, n. 4, p. 383-387, 2007.

BRUNDRETT, M.; BOUGHER, N.; DELL, B.; GROVE, T.; MALAJCZUK, N. Working with Mycorrhizas in Foresty and Agriculture. ACIAR, Canberra, 1996. 374 p.

CALDEIRA, M. V. W.; WENDLING, I.; PENCHEL, R. M.; GONÇALVES, E. O.; KRATZ, D.; TRAZZI, P. A. Propriedades de substratos para produção de mudas florestais. In: CALDEIRA, M. V. W.; GARCIA, G. O.; GONÇALVES, E. O.; ARANTES, M. D. C.; FIEDLER, N. C. (Eds.). Contexto e perspectivas da área florestal no Brasil. Visconde do Rio Branco: Suprema, 201 I. p. I4I-160.

CARDOSO FILHO, J. A.; PASCHOLATI, S. F.; SABRINHO, R. R. Mycorrhizal Association and Their Role in Plant Disease Protection. In: HAKEEM, K. R.; AKHTAR, M. S. (Eds.). Plant, Soil and Microbes, v 2: Mechanisms and Molecular Interactions. Springer, 2016. p. 95-143.

CECCAROLI, P.; SALTARELLI, R.; POLIDORI, E.; BARBIERI, E.; GUESCINI, M.; CIACCI, C.; STOCCHI, V. Sugar transporters in the black truffle Tuber melanosporum: from gene prediction to functional characterization. Fungal Genetics and Biology, v. 8I, p. 52-6I, 2015.
DICKSON, A.; LEAF, A. L.; HOSNER, J. F. Quality appraisal of white spruce and white pine seedling stock in nurseries. The Forest Chronicle, v. 36, n. I, p. 10-13, 1960.

FABROWSKI, F. J.; MUÑIZ, G. I. B.; NAKASHIMA, T.; NISGOSKI, S.; KLOCK, U. Investigation of essential oil presence in Eucalyptus smithii r.t. Baker through wood and bark anatomy. Ciência Florestal, v. I3, n. I, p. 95-106, 2003.

FERREIRA, D. F. SISVAR: A computer statistical analysis system. Ciência e Agrotecnologia, v. 35, n. 6, p. 1039-1042, 201 I.

FRANK, A. B. Die Bedeutung der Mykorrhizapilze für die gemeine Kiefer. Forstwissenschaftliches Centralblatt, v. 16, p. 185-190, 1894.

GLASSMAN, S. I.; LEVINE, C. R.; DIROCCO, A. M.; BATTLES, J. J.; BRUNS, T. D. Ectomycorrhizal fungal spore bank recovery after a severe forest fire: some like it hot. Multidisciplinary Journal of Microbialecology, v. 10, p. 1228-1239, 2016.

GIOVANETTI, M. G.; MOSSE, B. An evaluation of techniques for measuring vesicular-arbuscular mycorrhizal infection in roots. New Phytologist, v. 84, n. 3, p. 489-500, 1980.

GURGEL, F. E.; SILVA, B. D. B.; BASEIA, I. G. New records of Scleroderma from Northeastern Brazil. Mycotaxon, v. 105, p. 399-405, 2008.

GURGEL, F. E. Fungos ectomicorrízicos em áreas de Mata Atlântica do Nordeste do Brasil. 2009. 55 p. Dissertação de Mestrado. Universidade Federal do Rio Grande do Norte, Natal.

HADDI, K.; OLIVEIRA, E. E.; FARONI, L. R. A.; GUEDES, D. C.; MIRANDA, N. N. S. Sublethal exposure to Clove and Cinnamon essential oils induces hermetic like responses and disturbs behavioral and respiratory responses in Sitophilus zeamais (Coleoptera: Curculionidae). Journal of Economic Entomology, v. 108, n. 6, p. 2815-2822, 2015.

HODGE, A.; FITTER, A. H. Microbial mediation of plant competition and community structure. Mechanisms of plant competition, v. 27, n. 4, p. 865-875, 2013.

JOHNSON, D.; MARTIN, F.; CAIRNEY, J. W. G.; ANDERSON, I. C. The importance of individuals: intraspecific diversity of mycorrhizal plants and fungi in ecosystems. New Phytologist, v. 194, n. 3, p. 614-628, 2012.

LORENZI, H. Árvores brasileiras: manual de identificação e cultivo de plantas arbóreas nativas do Brasil. Instituto Plantarum, 2014. 384p.

MAIRESSE, L. A. S. Avaliação da bioatividade de extratos de espécies vegetais, enquanto excipientes de aleloquímicos. 2005. 340 p. Tese de Doutorado, Universidade Federal de Santa Maria, Santa Maria. 
MARTINS, A.; BAPTISTA, P.; RODRIGUES, P.; PAIS, M. S. Estudos e perspectivas futuras das micorrizas e da indução de micorrização in vitro e ex vitro de Castanea sativa Mill. Anais da Associação Micológica "A Pantorra" - A Floresta e os Cogumelos, v. 5, p. 59-78, 2005.

MIRANSARI, M.; ABRISHAMCHI, A.; KHOSHBAKHT, K.; NIKNAM, V. Plant hormones as signals in arbuscular mycorrhizal symbiosis. Critical Reviews in Biotechnology, v. 34, n. 2, p. 123-133, 2014.

MOLINA, R.; MASSICOTTE, H. B. E.; TRAPPE, J. M. Specificity phenomena in mycorrhizal simbioses: communityecological consequences and pratical implications. In: ALLEN, M. F.; HALL, C. (eds.). Mycorrhizal Functioning, Chapman \& Hall, London, 1992. p. 357-423.

NARA, K.; HOGETSU, T. Ectomycorrhizal fungi on established shrubs facilitate subsequent seedling establishment of successional plant species. Ecology, v. 85, n. 6, p. I700-I707, 2004.

NEILSON, E. H.; GOODGER, J. Q. D.; WOODROW, I. E.; MOLLER, B. L. Plant chemical defense: at what cost? Trends in Plant Science, v. I8, n. 5, p. 250-258, 2013.

OLIVEIRA, V. L.; ROSSI, M. J.; TARGHETTA, B. L. Avanços na aplicação de ectomicorrizas. In: FIGUEIREDO, M. V. B.; BURITY, H. A.; STAMFORD, N. P.; SANTOS, C. E. R. S. (eds.). Microrganismos e agrobiodiversidade: o novo desafio para a agricultura. Agrolivros, Guaíba, 2008. p. 297-331.

OLIVEIRA, V. L.; OLIVEIRA, L. P.; ROSSI, M. J. Ectomicorrizas no Brasil: diversidade de fungos e aplicação. In: SIQUEIRA, J. O.; SOUZA, F. D.; CARDOSO. E. J. B. N.; TSAI, S. M. (eds.). Micorrizas: 30 anos de pesquisas no Brasil. Universidade Federal de Lavras, Lavras, 2010. p. 645-677.

PAGANO, M. C.; CORREA, E. J. A.; DUARTE, N. F; YELIKBAYEV, B.; O'DONOVAN, A.; GUPTA, V. K. Advances in Eco-Efficient Agriculture: The Plant-Soil Mycobiome. Agriculture, v. 7, n. 2, p. 4-12, 2017.

PETERSON, R. L.; MASSICOTTE, H. B.; MELVILLE, L. H. Mycorrhizas: anatomy and cell biology. NRC Research Press, 2004. 173 p.

RAUDASKOSKI, M.; KOTHE, E. Novel findings on the role of signal exchange in arbuscular and ectomycorrhizal symbioses. Mycorrhiza, v. 25, n. 4, p. 243-252, 2015.

SERAFINI, L. A.; CASSEL, E. Produção de óleos essenciais: uma alternativa para a agroindústria nacional. In: SERAFINI, L. A.; BARROS, N. M.; AZEVEDO, J. L. (eds.). Biotecnologia na agricultura e na agroindústria. Agroindústria, Guaíba, 200I. p. 333-377.

SILVA, R. F.; ANTONIOLLI, Z. I.; LUPATINI, M.; TRINDADE, L. L. Ectomicorrização em quatro espécies florestais nativas do Rio Grande do Sul e sua eficiência em solo contaminado por cobre. Ciência e Natura, v. 33, n. 2, p. 95-109, 201 I.
SIMAS, D. L. R.; DE AMORIM, S. H. B. M.; GOULART, F. R. V.; ALVIANO, C. S.; ALVIANO, D. S.; DA SILVA, A. J. R. Citrus species essential oils and their components can inhibit or stimulate fungal growth in fruit. Industrial Crops and Products, v. 98, p. 108-1 15, 2017.

SMITH, S. E.; READ, D. J. Mycorrhizal symbiosis. Academic Press, San Diego, 2008. 787p.

SOYTONG, K.; SIBOUNNAVONG, P.; KANOKMEDHAKUL, K.; KANOKMEDHAKUL, S. Biological active compounds of Scleroderma citrinum that inhibit plant pathogenic fungi. Journal of Agricultural Technology, v. 10, n. I, p. 79-86, 2014.

STEFFEN, R. B.; ANTONIOLLI, Z. I.; STEFFEN, G. P. K.; SILVA, R. F. Essential oil of Eucalyptus grandis Hill ex Maiden in stimulating mycorrhizal sibipiruna seedlings (Caesalpinia peltophoroides Benth.). Ciência Florestal, v. 22, n. I, p. 69-78, 2012.

STEFFEN, R. B.; ANTONIOLLI, Z. I.; STEFFEN, G. P. K.; JACQUES, R. J. S.; SANTOS, M. L.; GODOY, H. T.; BOGUSZ JÚNIOR, S. Eucalyptus essential oil as biostimulator of the growth of in vitro ectomycorrhizal fungi. Ciência Florestal, v. 23, n. 2, p. 403-4I4, 2013.

SIMAS, D. L. R.; AMORIM, S. H. B. M. de; GOULART, F. R. V.; ALVIANO, C. S.; ALVIANO, D. S.; SILVA, A. J. R. da. Citrus species essential oils and their components can inhibit or stimulate fungal growth in fruit. Industrial Crops and Products, v. 98, p. 108-II5, 2017.

SULZBACHER, M. A. Fungos ectomicorrízicos do sul do Brasil, com ênfase no hábito hipógeo. 2010. 129p. Dissertação de Mestrado, Universidade Federal de Santa Maria, Santa Maria.

SULZBACHER, M. A.; GREBENC, T.; JACQUES, R. J. S.; ANTONIOLLI, Z. I. Ectomycorrhizal fungi from southern Brazil - a literature-based review, their origin and potential hosts. Mycosphere, v. 4, n. I, p. $61-95,2013$

TRAPPE, J. M.; BERCH, S. M. The prehistory of mycorrhizae: A.B. Frank's predecessors. In MOLINA, R. (Editor). Proceedings of the 6th North American conference on Mycorrhizae. Corvallis: Forest Research Laboratory, Oregon State University, 1985. p. 2-II.

VITTI, A. M. S.; BRITO, J. O. Óleo essencial de Eucalipto. São Paulo: Universidade de São Paulo, Documentos 17. 2003. 26p.

WRIGHT, J. E.; ALBERTÓ, E. Hongos: Guia de la region pampeana. Volumen 2: Hongos sin laminillas. L.O.L.A., Buenos Aires, 2006. 4I2p. 